\title{
KANDUNGAN RHODAMIN B PADA SEDIAAN LIP TINT YANG DIGUNAKAN MAHASISWI STIKES PELAMONIA
}

\author{
Content of Rhodamin B In Lip Tint used by Students of Stikes Pelamonia
}

\section{A. Asmawati Sa’ad*, Desi Reski Fajar, Tuti Alawiyah}

Stikes Pelamonia Kesdam VII/Wrb

*Email : asmasaad88@gmail.com

DOI: https://doi.org/10.32382/mf.v15i2.1122

\section{ABSTRACT}

Rhodamine B is a synthetic dye used for coloring paper, textiles, or inks. However, it irritates the respiratory tract, apart from being carcinogenic. In high concentrations, Rhodamine B might lead to liver damage. The purpose of this study is to determine the presence of rhodamine B content in lip tint used by female students of the Institute of Health Science Pelamonia. The study uses a thin layer chromatography and UV-Vis spectrophotometry methods. The qualitative analysis of rhodamine $B$ was carried out by thinlayer chromatography (TLC) using eluent ethyl acetate, n-butanol, and ammonia (55:20:25) which produces pink stains in case it is viewed visually and yellow fluorescence under UV light $254 \mathrm{~nm}$. Importantly, quantitative analysis was performed by determining the levels of UV-Vis spectrophotometry with a wavelength of $545 \mathrm{~nm}$. There are four samples analyzed with codes A1, A2, A3, and A4. The results showed that from the qualitative analysis using the thin layer chromatography method, there were two samples containing rhodamine B, including A2 and A4 codes. Also, the rhodamine B levels in the sample examined with A2 were $34.0 \mathrm{mg} / \mathrm{kg}$ and $419 \mathrm{mg} / \mathrm{kg}$ for $\mathrm{A} 4$.

Keywords: Lip Tint, Rhodamin B, Thin Layer Chromatography, UV-Vis Spectrophotometry

\section{ABSTRAK}

Rhodamin B merupakan pewarna sintesis yang biasa digunakan untuk pewarna kertas, tekstil maupun tinta. Rhodamin B dapat menyebabkan iritasi pada saluran pernapasan dan merupakan karsinogenik,rhodamin B dalam konsentrasi yang tinggi dapat menyebabkan kerusakan pada hati. Penelitian ini bertujuan untuk mengetahui apakah ada kandungan rhodamin B pada sediaan lip tint yang digunakan mahasiswi STIKES Pelamonia dengan menggunakan metode kromatografi lapis tipis dan berapa kadar kandungan rhodamin B pada sediaan lip tint yang digunakan mahasiswi STIKES Pelamonia dengan menggunakan metode spektrofotometri UV-Vis. Analisis kualitatif rhodamin B dilakukan dengan metode kromatografi lapis tipis (KLT) dengan menggunakan eluen etil asetat, n-butanol, amoniak (55:20:25) yang menghasilkan noda berwarna merah muda jika dilihat secara visual dan memberikan fluoresensi kuning jika dilihat dibawah sinar UV $254 \mathrm{~nm}$. Analisis kuantitatif dilakukan dengan menentukan kadar pada spektrofotometri UV-Vis dengan panjang gelombang $545 \mathrm{~nm}$. Terdapat empat sampel yang dianalisis dengan kode sampel A1, A2, A3, dan A4. Hasil menunjukkan bahwa dari analisis kualitatif menggunakan metode kromatografi lapis tipis terdapat dua sampel yang mengandung rhodamin $\mathrm{B}$ yaitu sampel dengan kode A2 dan A4, kadar rhodamin B pada sampel yang diperiksa dengan kode A2 sebesar 34,0 mg/kg dan untuk sampel kode A4 sebesar 41,9 mg/kg.

Kata Kunci: Lip Tint, Rhodamin B, Kromatografi Lapis Tipis, Spektrofotometri UV-Vis

\section{PENDAHULUAN}

Saat ini kosmetik sudah menjadi kebutuhan penting bagi manusia, terutama kaum wanita. Kosmetik tidak saja digunakan untuk fungsi estetika, namun memiliki peran dalam penyembuhan dan perawatan kulit. Meski bukan kebutuhan primer, tetapi kosmetik merupakan salah satu produk yang digunakan secara rutin dan terus menerus oleh manusia.
Kosmetik adalah bahan atau sediaan yang dimaksudkan untuk digunakan pada bagian luar tubuh manusia (epidermis, rambut, kuku, bibir, dan organ genital bagian luar) atau gigi dan membran mukosa mulut, terutama untuk membersihkan, mewangikan, mengubah penampilan, dan/atau memperbaiki bau badan atau melindungi atau memelihara tubuh pada kondisi baik (BPOM, 2015). 
Pada umumnya di pasaran sudah banyak beredar sediaan kosmetik, salah satu produk kosmetik yang sering digunakan bagi kaum wanita adalah lip tint. Lip tint merupakan jenis lipstik yang memiliki bentuk yang berbeda dari lipstik pada umumnya. Dimana diketahui lipstik pada umumnya dikemas dalam bentuk batang padat (rool up) yang terbuat dari minyak, lilin dan lemak. Bila pengemasannya dilakukan dalam bentuk batang lepas itulah yang disebut lip tint. Sebenarnya lipstik juga merupakan lip tint yang diberi pengungkit roll up untuk memudahkan pemakaiannya dan sedikit lembut dan mudah dipakai. Lip tint dapat berbentuk cair, krim, pensil atau spidol yang warnanya lebih tahan lama. Lip tint yang baik adalah lip tint yang dapat mempercantik warna bibir dan mampu memberikan nutrisi serta melembabkan bibir. Salah satu zat utama dalam formulasi lip tint adalah zat warna. Tujuan dari penambahan pewarna pada lip tint adalah untuk memberikan warna yang cerah, dan segar pada bibir. Selain itu, zat pewarna ditambahkan agar daya tarik konsumen terhadap produk meningkat. Namun, ada beberapa produsen yang menggunakan zat warna yang tidak semestinya seperti penggunaan rhodamin B.

Berdasarkan hasil investigasi BPOM tahun 2014, terdapat 9.817 produk kosmetik yang tidak memenuhi izin edar dan produk dengan bahan yang berbahaya atau dilarang. Dari hasil pemeriksaan, bahan berbahaya yang ditemukan adalah merkuri, hidrokuinon dan zat pewarna rhodamin $\mathrm{B}$.

Rhodamin B merupakan zat warna sintesis berbentuk serbuk kristal, berwarna hijau atau ungu kemerahan, tidak berbau, larutan dalam air berwarna merah kebiruan/berfluoresensi kuat. Rhodamin B digunakan sebagai zat warna untuk kertas, tekstil, wool, sutra, dan sebagai reagensia untuk analisis antimon, kobalt, bismut, dan lain-lain (BPOM, 2008).

Penggunaan jangka pendek dari rhodamin B pada kulit dapat menyebabkan iritasi. Jika digunakan pada bibir manusia, rhodamin B dapat menghambat proses dari sintesis protein non-spesifik yang dapat berakibat mengurangi kandungan kolagen dari lapisan sel fibroblast pada bibir manusia. Rhodamin B dapat menyebabkan iritasi pada saluran pernapasan dan merupakan zat karsinogenik. Dalam konsentrasi tinggi dapat menyebabkan kerusakan pada hati (BPOM, 2014).

Ciri-ciri produk yang mengandung rhodamin B adalah warnanya cerah mengkilap dan lebih mencolok, terkadang warnanya terlihat tidak homogen (rata), adanya gumpalan warna pada produk, tidak mencantumkan kode, label, merek, informasi kandungan, atau identitas lengkap lainnya (Purniati dkk., 2015).

Untuk mengidentifikasi kandungan rhodamin B didalam sediaan lip tint dapat dilakukan identifikasi kualitatif dengan menggunakan metode kromatografi lapis tipis (KLT) dan identifikasi kuantitatif dengan menggunakan metode spektrofotometri UV-Vis. Kelebihan metode KLT yaitu metodenya sederhana dan juga memiliki ketelitian yang baik, selain itu dapat menghasilkan pemisahan yang lebih sempurna dan kepekaan yang lebih tinggi. Kelebihan penggunaan spektrofotometri UV-Vis yaitu panjang gelombang dari sinar putih dapat lebih terseleksi, caranya sederhana, dan dapat menganalisa larutan dengan konsentrasi yang sangat kecil. Selain itu, kelebihan metode ini dapat menghasilkan absorbans maksimum lebih besar dan analisanya lebih cepat. Dari uraian diatas maka peneliti tertarik untuk melakukan penelitian dengan judul analisis kandungan rhodamin B pada sediaan lip tint yang digunakan mahasiswi STIKES Pelamonia dengan metode kromatografi lapis tipis dan spektrofotometri UV-Vis.

Penelitian ini bertujuan untuk mengetahui apakah ada kandungan rhodamin B pada sediaan lip tint yang digunakan mahasiswi STIKES Pelamonia dengan menggunakan metode kromatografi lapis tipis dan berapa kadar kandungan rhodamin B pada sediaan lip tint yang digunakan mahasiswi STIKES Pelamonia dengan menggunakan metode spektrofotometri UV-Vis.

\section{METODE}

Jenis penelitian yang digunakan adalah penelitian eksperimental laboratorium dengan menggunakan analisis deskriptif, data yang dicari adalah data kualitatif dan kuantitatif. Data kualitatif diperoleh dengan menggunakan metode kromatografi lapis tipis (KLT) dan data kuantitatif diperoleh dengan menggunakan metode Spektrofotometri UV-Vis. Penelitian ini dilaksanakan pada bulan Juli tahun 2019. Bertempat di Balai Besar Laboratorium Kesehatan Makassar (BBLKM).

\section{Jumlah dan Cara Pengambilan Subyek}

Dalam penelitian ini yang menjadi populasi adalah seluruh sediaan lip tint yang digunakan mahasiswi STIKES Pelamonia. Adapun total keseluruhan jumlah populasi yang terdapat di Kampus STIKES Pelamonia sebanyak 9 merek.Pada penelitian ini sampel 
dihitung menggunakan rumus $\sqrt{n}+1$. Dimana $\mathrm{n}$ adalah populasi. Jadi diperoleh $\sqrt{9}+1=$ 4. Berdasarkan perhitungan, diambil 4 jenis sampel lip tint dengan kode A1, A2, A3 dan A4.Teknik pengambilan sampel pada penelitian ini menggunakan teknik pengambilan sampel secara non random yaitu purposive sampling. Purposive sampling adalah pengambilan sampel secara purposive didasarkan pada pertimbangan tertentu yang dibuat oleh peneliti sendiri seperti sampel yang diambil adalah lip tint yang berwarna merah, lip tint yang tidak dicantumkan komposisinya, merek lip tint yang paling banyak diminati oleh mahasiswi kampus STIKES Pelamonia

\section{Alat dan Bahan}

Alat yang digunakan adalah aluminium foil, batang pengaduk, corong pisah (pyrex), chamber, gelaskimia, labu ukur, lampu UV 254 $\mathrm{nm}$ dan $366 \mathrm{~nm}$, neraca analitik, plat KLT, pipa kapiler, pipet volum, pinset, spatula logam, spektrofotometer UV-Vis (Varian Cary 50 Bio $U V$-Visible).Bahan yang digunakan dalam penelitian ini adalah amoniak $25 \%$, asam posfat, etanol $96 \%$, etil asetat, dimetilformamida, nbutanol, n-heksan, rhodamin B, sampel lip tint.

\section{ProsedurPenelitian}

\section{Analisis Kualitatif dengan Metode Kromatografi Lapis Tipis}

Tahap ini dilakukan berdasarkan prosedur (PerKaBPOM) Nomor HK. 03.1.23.08.11.07331 Tahun 2011

a. Penyiapan Larutan Baku

Timbang 0,1 gr rhodamin B dan dilarutkan dengan etanol $96 \%$ sebanyak $100 \mathrm{ml}$, kemudian dikocok hingga larut.

b. Penyiapan Larutan Pelarut Campur $(95: 5) \mathrm{v} / \mathrm{v}$

Dimetilformamida - asam posfat

c. Penyiapan Larutan Uji

Timbang sampel sebanyak $0,1 \mathrm{gr}$ dan larutkan dalam $2 \mathrm{ml}$ pelarut campur. Lakukan ekstraksi lemak 2 kali, setiap kali dengan $5 \mathrm{ml}$ n-heksan. Kumpulkan ekstrak n-heksan. Jika ekstrak berwarna, ekstraksi kembali dengan $2 \mathrm{ml}$ pelarut campur dan buang lapisan n-heksan.

d. Penyiapan Larutan Eluen Etil asetat - n-butanol ammonia 25\% (20:55:25) v/v/v

e. Prosedur KLT

Lempeng KLT berukuran $20 \mathrm{X}$ $20 \mathrm{~cm}$ diaktifkan dengan cara dipanaskan dalam oven pada suhu $105^{\circ} \mathrm{C}$ selama 2-3 jam. Sampel ditotolkan pada lempeng
KLT dengan menggunakan pipa kapiler pada jarak $2 \mathrm{~cm}$ dari bagian bawah plat, jarak antara noda adalah $1,5 \mathrm{~cm}$.. Lempeng KLT yang telah mengandung cuplikan dimasukkan kedalam chamber yang terlebih dahulu dijenuhkan dengan fase gerak berupa etil asetat : n-butanol : ammonia $25 \% \quad(20: 55: 25)$. Dibiarkan hingga lempeng terelusi sempurna, kemudian lempeng KLT diangkat dan dikeringkan. Diamati warna secara visua,1 nodanampak berwarna merah muda dan dibawah sinar UV $254 \mathrm{~nm}$ dan $366 \mathrm{~nm}$ berfluoresensi kuning atau orange, hal ini menunjukkan adanya rhodamin $\mathrm{B}$. selanjutnya dihitung nilai Rfnya, hasil dinyatakan positif jika bila mana bercak antara sampel dengan baku sama atau saling mendekati dengan selisih harga $\leq 0,2$ dengan rumus :

$$
\mathrm{Rf}=\frac{\text { jarak yang ditempuh solut }}{\text { jarak yang ditempuh fase gerak }}
$$

\section{Analisis Kuantitatif dengan Metode Spektrofotometri Uv-Vis}

a. Pembuatan Larutan Baku Rhodamin B 1000 ppm

Ditimbang $0,1 \quad \mathrm{~g}$ pewarna rhodamin B dimasukkan ke dalam labu ukur $100 \mathrm{ml}$, didalam labu ukur ditambahkan etanol 96\% secukupnya dan dikocok hingga homogen. Kemudian larutan dicukupkan dengan etanol $96 \%$ hingga garis tanda kemudian dihomogenkan.

b. Pembuatan Larutan Baku Rhodamin B 100 ppm

Dipipet $1 \mathrm{ml}$ larutan rhodamin B 1000 ppm dengan menggunakan pipet volum kemudian dimasukkan kedalam labu ukur $100 \mathrm{ml}$ lalu ditambahkan etanol 96\% sampai garis tanda.

c. Penentuan Panjang Gelombang Maksimum Larutan Rhodamin B

Dipipet $3 \mathrm{ml}$ larutan rhodamin B 100 ppm dengan menggunakan pipet volum dan dimasukkan kedalam labu ukur $100 \mathrm{ml}$ (konsentrasi 3 ppm), lalu ditambahkan etanol $96 \%$ sampai garis tanda dan dihomogenkan. Diukur serapan maksimum pada panjang gelombang 400$800 \mathrm{~nm}$ dengan menggunakan blangko. Blangko yang digunakan adalah etanol $96 \%$.

d. Penentuan Kurva Kalibrasi

Dari larutan rhodamin B 100 ppm dipipet sebanyak $1 \mathrm{ml}, 2 \mathrm{ml}, 3 \mathrm{ml}, 4$ $\mathrm{ml}, 5 \mathrm{ml}$ dengan menggunakan pipet 
volum dan dimasukkan ke labu ukur 100 $\mathrm{ml}$ (konsentrasi masing-masing larutan 1, 2, 3, 4, $5 \mathrm{mg} / \mathrm{L}$ ). Kemudian diukur serapannya pada panjang gelombang maksimum yang diperolh dan sebagai blanko digunakan etanol $96 \%$ akan diperoleh kurva kalibrasi Vs absorbansi.

e. Preparasi Sampel

Diambil konsetrat sampel sebanyak 0,5 $\mathrm{ml}$ menggunakan pipa kapiler kemudian ditotolkan pada plat KLT yang telah diaktifkan pada oven dengan suhu $105^{\circ} \mathrm{C}$ selama 2-3 jam. Setelah ditotolkan pada plat, dimasukkan ke chamber eluen yang isinya etil asetat, n-butanol, ammonia (55:20;25). Kemudian plat KLT ditunggu beberapa saat sampai terelusi semua. Kemudian plat dikeluarkan dari chamber lalu dikeringkan pada suhu ruangan. Kemudian diamati dibawah sinar UV 254 dan $366 \mathrm{~nm}$. Sampel yang berfluoresensi pada plat dikeruk kemudian dilarutkan dengan etanol $96 \%$ sebanyak $5 \mathrm{ml}$ kemudian didiamkan beberapa saat (larutan uji).

f. Penetapan Kadar

Diambil larutan uji yang telah diekstraksi, dimasukkan kedalam kuvet kemudian dimasukkan kealat spektrofotometer dan diukur pada panjang gelombang maksimum yang diperoleh dan sebagai blanko digunakan etanol $96 \%$.

g. Penggunaan alat Spektrofotometri UVVis

Pengoperasian alat spektrofotmetri UV-Vis cary 50 yaitu dengan menekan tombol $\mathrm{ON}$ apabila aliran listrik telah dihubungkan, maka indikator akan berwarna merah menandakan adanya aliran listrik yang mengalir. Dibiarkan kurang lebih 15 menit untuk memanaskan alat. Dipilih panjang gelombang yang digunakan dengan cara memilih dari tombol pengaturan modenya, dimasukkan larutan blanko dan standar untuk mengukur absorbannya. Kemudian dibaca absorbennya yang ditunjukkan pada alat kemudian hasil dikeluarkan dengan print out.

\section{Pengolahan dan Analisis Data}

Perhitungan kadar Rhodamin B dalam sampel sediaan lip tint

Keterangan :

$$
\mathrm{K}=\frac{X \times V \times F p}{B s}
$$

$\mathrm{K}=$ Kadar Rhodamin B dalam sampel (mg/L)

$\mathrm{X}=$ Kadar Rhodamin sesudah pengenceran

$\mathrm{V}=$ Volume sampel

$\mathrm{Fp}=$ Faktor Pengenceran

$\mathrm{Bs}=$ Berat sampel

Data yang diperoleh dari hasil uji zat warna rhodamin B, kemudian dikumpulkan, dianalisa secara deskriptif.

\section{HASIL}

Penelitian telah dilakukan di Balai Besar Laboratorium Kesehatan Makassar dengan jumlah sampel empat lip tint yang digunakan mahasiswi STIKES Pelamonia. Kandungan rhodamin B pada sampel lip tint dilakukan dengan analisis kualititatif dengan menggunakan metode KLT dan analisis kuantitatif dengan menggunakan metode spektrofotometri UV-Vis.

Hasil penelitian didapatkan bahwa ada dua sampel yang memberikan hasil positif yang dianalisis dengan menggunakan metode KLT yaitu sampel dengan kode A2 dan A4. Sampel kode A2 dan A4 masing-masing mempunyai nilai $\mathrm{Rf}$ dari pembanding adalah 0,45 dan nilai $\mathrm{Rf}$ dari sampel sendiri adalah 0,45. Analisis kuantitatif rhodamin B dilakukan dengan menggunakan metode spektrofotometri UV-Vis. kadar rhodamin B yang didapatkan pada sampel kode A2 sebesar 34,0 mg/kg dan pada sampel kode A4 sebesar 41,9 mg/kg.

Tabel 1. Data pengujian kualitatif dengan menggunakan Metode KLT

\begin{tabular}{ccccccc}
\hline \multirow{2}{*}{$\begin{array}{c}\text { N } \\
\text { o }\end{array}$} & No. Lab & $\begin{array}{c}\text { Kode } \\
\text { Sampel }\end{array}$ & \multicolumn{2}{c}{ Warna } & \multicolumn{2}{c}{ Rf } \\
\cline { 5 - 7 } 1 & 19013679 & A1 & Ungu & $\begin{array}{c}\text { Tidak } \\
\text { berfluoresensi }\end{array}$ & 0,45 & - \\
2 & 19013680 & A2 & $\begin{array}{c}\text { Merah } \\
\text { muda }\end{array}$ & $\begin{array}{c}\text { Berfluoresensi } \\
\text { kuning }\end{array}$ & 0,45 & 0,45 \\
2 & 19013681 & A3 & Orange & $\begin{array}{c}\text { Tidak } \\
\text { berfluoresensi }\end{array}$ & 0,4 & Sampel
\end{tabular}




\begin{tabular}{lllcccc}
3 & 19013682 & A4 & $\begin{array}{c}\text { Merah } \\
\text { muda }\end{array}$ & $\begin{array}{c}\text { Berfluoresensi } \\
\text { kuning }\end{array}$ & 0,45 & 0,45 \\
\hline
\end{tabular}

Tabel 2. Data pengujian kuantitatif kadar rhodamin B pada sampel dengan panjang gelombang $545 \mathrm{~nm}$

\begin{tabular}{ccccc}
\hline \multirow{2}{*}{ No } & No. Lab & $\begin{array}{c}\text { Kode } \\
\text { Sampel }\end{array}$ & & \multicolumn{2}{c}{ Kadar Rhodamin B } \\
\cline { 4 - 5 } & & & Kualitatif & $\begin{array}{c}\text { Kuantitatif } \\
(\mathrm{mg} / \mathrm{kg})\end{array}$ \\
\hline 1 & 19013679 & A1 & Negatif & - \\
2 & 19013680 & A2 & Positif & $34,0 \mathrm{mg} / \mathrm{kg}$ \\
2 & 19013681 & A3 & Negatif & - \\
3 & 19013682 & A4 & Positif & $41,9 \mathrm{mg} / \mathrm{kg}$ \\
\hline
\end{tabular}

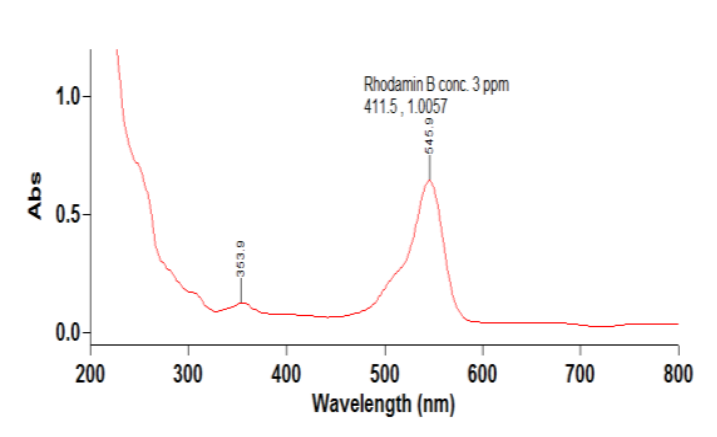

Gambar 1.Panjang gelombang larutan baku rhodamin B

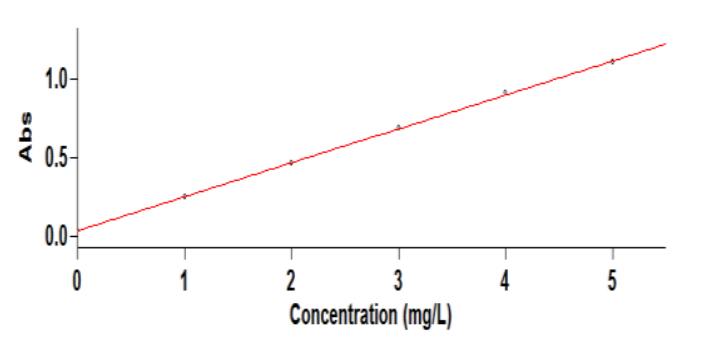

Gambar 2. Data kurva kalibrasi larutan baku rhodamin B pada konsentrasi $1 \mathrm{mg} / \mathrm{L}, 2 \mathrm{mg} / \mathrm{L}, 3 \mathrm{mg} / \mathrm{L}$, $4 \mathrm{mg} / \mathrm{L}$, dan $5 \mathrm{mg} / \mathrm{L}$

\section{PEMBAHASAN}

Sebelum dilakukan uji kuantitatif rhodamin B pada sampel, perlu dilakukan identifikasi untuk mengetahui ada tidaknya rhodamin B pada sampel dengan menggunakan metode kromatografi lapis tipis (KLT).

Pengujian dilakukan dengan cara menotolkan sampel yang telah dipekatkan pada plat KLT kemudian dielusi dengan menggunakan eluen etil asetat : n-butanol : amoniak dengan perbandingan 55:20:25. Kemudian noda hasil KLT dilihat secara visual dan dilihat dibawah sinar UV pada panjang gelombang 254 dan $366 \mathrm{~nm}$.

Penggunaan eluen berupa etil asetat, nbutanol, amoniak dengan perbandingan 55:20:25, berfungsi sebagai fase air atau fase gerak untuk menciptakan suasana organik 
sehingga sampel dapat terdistribusi dari fasa air ke fasa organik. Semakin dekat kepolaran antara sampel dengan eluen maka sampel akan semakin terbawa oleh fasa gerak tersebut (Purniati dkk., 2015).

Suatu senyawa yang mengandung rhodamin B akan mudah diamati. Secara visual akan memberikan warna merah muda pada plat KLT dan jika dilihat dibawah sinar UV akan berfluoresensi memberikan warna kuning atau orange (Ditjen POM,1997).

Dari tabel 1 dapat dilihat bahwa ada 2 sampel yang memberikan hasil positif yang diidentifikasi dengan menggunakan metode KLT, jika diamati secara visual dan diamati dibawah sinar UV yaitu sampel dengan kode A2 dan A4. Ini berarti sampel tersebut positif mengandung rhodamin $\mathrm{B}$.

Selain itu untuk mengidentifikasi suatu senyawa dapat kita lakukan dengan melihat nilai Rf nya. Dari tabel 1 dapat dilihat bahwa ada 2 sampel yang memberikan nilai Rf yang sejajar dengan pembandingnya. Sampel kode A2 dan A4 masing-masing mempunyai nilai Rf dari pembanding adalah 0,45 dan nilai Rf dari sampel sendiri adalah 0,45 . Hasil dinyatakan positif jika warna bercak antara sampel dan baku sama atau saling mendekati dengan selisih nilai $\leq 0,2$ (Depkes, 1998). Sehingga dapat disimpulkan bahwa kode sampel A2 dan A4 positif mengandung rhodamin $\mathrm{B}$.

Sampel yang positif mengandung rhodamin B pada uji kualitatif dilanjutkan pada uji kuantitatif untuk mengetahui kadar rhodamin B yang terkandung dalam sampel, pada uji kuantitatif pertama-tama ditentukan panjang gelombang maksimum larutan rhodamin B yang dilakukan pada konsentrasi 3 ppm dengan rentang panjang gelombang 200-800 nm. Hal ini dilakukan karena larutan rhodamin B merupakan larutan berwarna. Selain itu, pengukuran dilakukan pada rentang tersebut karena pada panjang gelombang maksimum, maka kepekaannya juga maksimum. Hasil penentuan panjang gelombang maksimum larutan baku rhodamin B pada konsentrasi 3 ppm diperoleh panjang gelombang maksimum sebesar $545 \mathrm{~nm}$. (Kurva serapan maksimum larutan rhodamin B pada konsentrasi $3 \mathrm{ppm}$ dapat dilihat pada gambar 1)

Dibuat konsentrasi larutan rhodamin B, dengan berbagai konsentrasi pengukuran yaitu, 1 $\mathrm{mg} / \mathrm{L}, 2 \mathrm{mg} / \mathrm{L}, 3 \mathrm{mg} / \mathrm{L}, 4 \mathrm{mg} / \mathrm{L}, 5 \mathrm{mg} / \mathrm{L}$ kemudian diukur serapannya pada panjang gelombang 545 $\mathrm{nm}$, dengan menggunakan blangko yaitu etanol 96\%. Larutan blangko digunakan untuk mengoreksi pembacaan atau spektrum sampel. Kemudian dibuat kurva yang merupakan hubungan antara absorbansi (y) dengan konsentrasi (x). Linieritas kurva kalibrasi larutan rhodamin B dapat dilihat pada gambar 2 .

Penetapan kadar Rhodamin B dilakukan dengan menggunakan spektrofotometri UV-Vis. Dari tabel 2 dapat dilihat bahwa kadar rhodamin B pada sampel kode A2 sebesar 34,0 mg/kg dan pada sampel kode A4 sebesar 41,9 mg/kg. Ini berarti kadar dalam kedua sampel cukup besar. Hal ini sangat membahayakan para konsumen karena semakin besar kemungkinan rhodamin B ini masuk kedalam tubuh dan memberikan efek toksik.

Rhodamin B adalah salah satu pewarna sintetik yang tidak boleh dipergunakan dalam kosmetik. Apabila dipergunakan sebagai pewarna kosmetik dapat menimbulkan iritasi pada kulit, serta menyebabkan kerusakan hati jika terpapar dengan konsentrasi yang tinggi (Putri, 2009). Hal itu disebabkan karena rhodamin B akan menumpuk dilemak sehingga dalam jangka waktu yang lama jumlahnya akan terus menerus bertambah didalam tubuh dan dapat mengakibatkan kerusakan pada organ tubuh sampai mengakibatkan kematian.

Rhodamin B dilarang digunakan untuk produk kosmetik khususnya pada lip tint. Hal ini disebabkan pada lokasi pemakaian jenis kosmetik tersebut yaitu bibir, merupakan daerah yang paling sensitif terhadap pemakaian pewarna tekstil. Efek rhodamin pada bibir dapat menimbulkan iritasi sampai terjadi peradangan. Pengaruh atau efek samping yang ditimbulkan dapat dijelaskan karena proses pembuatan zat warna sintesis umumnya melalui perlakuan dengan pemberian asam sulfat atau asam nitrat sering terkontaminasi oleh logam berat yang bersifat racun (Putri, 2009).

\section{KESIMPULAN}

Berdasarkan penelitian yang telah dilakukan, maka dapat disimpulkan bahwa :

1. Sediaan lip tint yang digunakan mahasiswi STIKES Pelamonia dengan menggunakan metode kromatografi lapis tipis ada yang positif mengandung rhodamin B yaitu sampel dengan kode A2 dan A4.

2. Kadar kandungan rhodamin B pada sediaan lip tint yang digunakan mahasiswi STIKES Pelamonia menggunakan metode spektrofotometri UV-Vis dengan kode A2 sebesar 34,0 mg/kg dan kode A4 sebesar 41,9 $\mathrm{mg} / \mathrm{kg}$. Hal ini dapat berbahaya bagi kesehatan tubuh mengingat rhodamin B dapat terakumulasi didalam tubuh dalam jangka waktu yang lama. 


\section{SARAN}

Kepada peneliti selanjutnya agar dapat melakukan pengidentifikasian zat pewarna rhodamin B dikosmetik lain seperti blush on.

\section{UCAPAN TERIMA KASIH}

Penulis mengucapkan terima kasih kepada laboran Balai Besar Laboratorium Kesehatan Makassar dan pihak prodi DIII Farmasi STIKES Pelamonia khususnya ibu A. Asmawati Sa'ad sebagai pembimbing pertama, dan Ibu Desi Reski Fajar,selaku pembimbing kedua.

\section{DAFTAR PUSTAKA}

BadanPengawasObatdanMakanan.2015.

PeraturanKepalaBadanPengawasObatdan MakananRepublik Indonesia TentangPersyaratanTeknisBahanKosmeti ka. Jakarta: Depkes RI.

BadanPengawasObatdanMakanan.2011. PeraturanKepalaBadanPengawasObatdan MakananRepublik Indonesia Nomor HK.03. 1. 23. 08. 11. 07331. Tahun 2011
TentangMetodeAnalisisKosmetik.

Jakarta: Depkes RI.

Badan Pengawas Obat dan Makanan. 2008. Rhodamin B. Jakarta: Depkes RI.

Badan Pengawas Obat dan Makanan. 2014. Penggunaan Rhodamin B Pada Kosmetik. Jakarta: Depkes RI.

Departemen Kesehatan RI. 1998. Pedoman Pengujian Mutu Sediaan Rias. Jakarta: Depkes RI.

Ditjen POM. 1997. Farmakope Indonesia Edisi Ketiga. Jakarta: Departemen Kesehatan RI.

Putri W. K. A. 2009. Pemeriksaan Penyalahgunaan Rhodamin B Sebagai Pewarna Pada Sediaan Lipstik Yang Beredar di Pusat Pasar Kota Medan. Medan : Universitas Sumatera Utara.

Purniati N.K., Rahman., Jura M.R. 2015. Identifikasi Zat Warna Rhodamin B Pada Lipstik Yang Beredar di Pasar Kota Palu.Palu : Universitas Tadulako. 